\title{
Safety Measures in Ophthalmology Practice in the COVID-19 Era
}

\section{Hany Mahmoud}

Lecturer of Ophthalmology, Faculty of Medicine, Sohag University, Sohag, Egypt Email:drhanymahmoud@gmail.com

\section{Abstract:}

Background: Coronavirus disease (COVID-19) has rapidly emerged as a global health threat as announced by the World Health Organization (WHO). The proximity between the ophthalmologist and the patient required during ophthalmological examination may put ophthalmologists at an increased risk of infection. Consequently, ophthalmologists need to have correct prevention strategies in place to avoid infection.

Methods: An internet based questionnaire was administered to ophthalmologists of Upper Egypt, Egypt. A total of 207 participants were included in the study. Full ethical considerations were followed.

Results: 71percent Of the participants followed the infection control measures with $94.2 \%$ used face mask, $80 \%$ used alcohol in ophthalmology practice, and others used many other methods or combinations. About $60 \%$ of the participants are planning to stop practice in the pandemic, about $40 \%$ do emergent surgical interventions only.

Conclusion: In order To minimize the transmission of COVID-19, ophthalmologists should work according to infection control measures that are appropriate for their own clinical settings.

Keywords: Conjunctivitis, Coronavirus, COVID-19, Infection control

\section{Introduction:}

Since it was first reported in Wuhan, China, on 31 December, 2019 [1], coronavirus disease (COVID-19) has rapidly emerged as a global health threat. The name COVID-19, which stands for coronavirus disease 2019, was proposed by the World Health Organization (WHO) [2].

COVID-19 is highly contagious and the World Health
Organization (WHO) declaring it a Public Health Emergency of International Concern on 30 January 2020 and a pandemic on 11 March 2020. As of 30, March 2020 , the ongoing outbreak of coronavirus disease 2019 (COVID-19) originating in Wuhan caused more than 770,000 confirmed cases and more than 37,000 deaths, with 178 countries affected worldwide [3]. There were Anecdotal reports have suggested that 
individuals may be infected by patients with subclinical infection [4], either by droplets or by direct contact with secretions from infected cases.

We, As ophthalmologists, we deal in close proximity with patients during slit lamp examination and direct ophthalmoscopy, which may pose an infectious risk to ophthalmologists because droplets from a cough or sneeze can travel up to six feet [5]. Moreover, ophthalmologists may also be caught off guard as conjunctivitis, though uncommon, could be the first presenting symptom of COVID19, before the appearance of other symptoms such as cough and fever [6].

The American Academy of Ophthalmology has issued an alert advising ophthalmologists to wear masks and eye protection when seeing conjunctivitis patients with respiratory symptoms and a history of international travel [7]. Also, protective shields (made of plastic) may be installed on slit lamps to lower the risk of transmission via droplet Hand hygiene is particularly important ,and ophthalmologists should practice hand hygiene using the WHO formula alcohol hand rub or hand washing after every patient encounter. If gloves were worn, they were removed ,followed by hand hygiene between cases [8].

Thus, the objective of this study was to assess the infection control measures among ophthalmologists in Upper Egypt.

\section{Methodology:}

A cross-sectional study was conducted among upper Egypt ophthalmologists in May 2020. The survey included ophthalmology residents, specialists, consultants, assistant lecturers, lecturers, assistant professors, and professors from nearly all medical health organizations in Upper Egypt.

We designed an internet-based questionnaire survey (Table 1) addressing the issue in 10 separate questions.

Ethical considerations were followed according to the Declaration of Helsinki 


\section{Results}

\begin{tabular}{|c|c|c|c|c|c|c|c|}
\hline $\begin{array}{l}\text { 1. Do you follow all instructions of infection } \\
\text { control in your practice? }\end{array}$ & Yes & No & $\begin{array}{l}\text { To some } \\
\text { extent }\end{array}$ & & & & \\
\hline & $147(71)$ & $14(6.8)$ & $46(22.2)$ & & & & \\
\hline $\begin{array}{l}\text { 2. Do you regulate patients' times to avoid } \\
\text { crowdness? }\end{array}$ & Yes & No & $\begin{array}{l}\text { To some } \\
\text { extent }\end{array}$ & & & & \\
\hline & $121(58.5)$ & $23(11.1)$ & $63(30.4)$ & & & & \\
\hline 3. Do the patients follow the instructions? & Yes & No & $\begin{array}{l}\text { To some } \\
\text { extent }\end{array}$ & & & & \\
\hline & $40(19.3)$ & $50(24.2)$ & $117(56.5)$ & & & & \\
\hline 4. What about surgeries? & $\begin{array}{l}\text { Emergency } \\
\text { only }\end{array}$ & $\begin{array}{l}\text { All } \\
\text { operations } \\
\text { with } \\
\text { precautions }\end{array}$ & $\begin{array}{l}\text { No } \\
\text { operations }\end{array}$ & & & & \\
\hline & $82(39.6)$ & $69(33.3)$ & $56(27.1)$ & & & & \\
\hline 5. What type of safety measures do you use? & Mask & Face shield & Alcohol & Gown & $\begin{array}{l}\text { Over } \\
\text { head }\end{array}$ & Gloves & Others \\
\hline & $195(94.2)$ & $30(14.5)$ & $166(80.2)$ & $\begin{array}{l}54 \\
(26.1)\end{array}$ & $\begin{array}{l}42 \\
(20.3)\end{array}$ & $\begin{array}{l}164 \\
(79.2)\end{array}$ & $\begin{array}{l}26 \\
(12.6)\end{array}$ \\
\hline 6. Are you planning to stop practice temporarily? & Yes & No & & & & & \\
\hline & $124(59.9)$ & $83(40.1)$ & & & & & \\
\hline 7. When and why? & Immediately & I don't Know & & & & & \\
\hline & $78(37.7)$ & $129(62.3)$ & & & & & \\
\hline $\begin{array}{l}\text { 8. Did you face a case of COVID-19 in your } \\
\text { practice? }\end{array}$ & Yes & No & $\begin{array}{l}\text { I don't } \\
\text { know }\end{array}$ & & & & \\
\hline & $34(16.4)$ & $61(29.5)$ & $112(54.1)$ & & & & \\
\hline $\begin{array}{l}\text { 9. What will you do if you faced a case of } \\
\text { COVID-19 in your practice? }\end{array}$ & Neglect & $\begin{array}{l}\text { Follow } \\
\text { infection } \\
\text { control } \\
\text { measures }\end{array}$ & Other & & & & \\
\hline & $19(9.2)$ & $184(89.3)$ & $3(1.5)$ & & & & \\
\hline
\end{tabular}

Values are $\mathrm{n}(\%)$.

*Multiple responses are permitted to this question. Because of the multiple responses, the sum of the percentages of the responses in these specific questions adds up to more than $100 \%$. 
The survey results are shown in Table 1. A total of 207 participants completed the questionnaires. A majority of the responders $(71 \%)$ followed the infection control measures, with at least $(56.5 \%)$ of patients who did not fully respond to infection control measures, but to some extent.

The most popular choices for providing safety were the face mask (94.2\%), followed by alcohol $(80.2 \%)$. The majority of participants $(59.9 \%)$ chose to stop practice at this time.

The 10th question asked participants to write down their medical degree and the organization where they worked.

\section{Discussion}

In the case of local outbreaks, the risk of infection to healthcare workers and patients is high. Ophthalmic practice carries some unique risks; therefore, high vigilance and special precautions are needed. This is because that conjunctivitis was reported to be present in $0.8 \%$ to $5.2 \%$ of COVID-19 patients [9].

Conjunctivitis can be the presenting symptom/sign of COVID-19; high vigilance is essential as conjunctivitis is a common condition in ophthalmic practice. Furthermore because eye centers could harbor asymptomatic patients with COVID-19 that have subtle or even no symptoms, proper precautions should be taken to protect both patients and staff from infection [10].

The number of patients visiting the clinic should be strictly limited, and there should be a strict timetable of appointments to prevent any agglomeration of patients in the clinic waiting room [11].

Universal masking, hand hygiene, and the correct use of PPE should be promoted [8]. Strict hand hygiene is required, and gloves should be changed regularly; one pair of latex gloves should not be used for long periods of time [11].

Direct ophthalmoscope examination is not recommended and can be replaced by slit light lenses, optical coherence tomography (OCT), or fundus photography [11].

According to current evidence, human coronavirus can remain infectious on inanimate surfaces for up to 9 days [12]. Therefore, reducing the viral load on surfaces by disinfection is very important. 
Non-urgent elective services and operations are advised to be reduced in order to reduce the risk of transmission due to people gathering. [8]. If ophthalmic surgery needs to be done, it should preferably be done under local anesthesia and not under general anesthesia, as endotracheal intubation is of aerosol generating nature [13].

\section{Conclusion:}

We need to step up our infection control measures immediately or else it may be too late to contain or control the spread of COVID19. In general, it is advisable to avoid going to places that are crowded with people, or with a higher risk of infection, such as clinics or hospitals. Good hand hygiene and proper use of PPE are other key preventive measures.

Financial interest : I have on financial interests.

\section{References:}

1. Huang C, Wang Y, Li X, et al. Clinical features of patients infected with 2019 novel coronavirus in Wuhan, China. Lancet. 2020; 395(10223):497-506.

2. WHO Director-General's remarks at the media briefing on 2019-nCoV on
11 February 2020. (2020)

World

Health

Organization. https://www.w ho.int/dg/speeches/detail/who -director-general-s-remarksat-the-media-briefing-on2019-ncov-on-11-february2020. Accessed 18 Feb 2020.

3. Dong E, Du H and Gardner L. An interactive web-based dashboard to track COVID19 in real time. Lancet Infect Dis 2020;20:533-4.

4. Chang, Xu H, Rebaza A, et al. protecting health-care workers from subclinical coronavirus infection. Lancet Respir Med. 2020 Mar;8(3):e13.

5. How Flu Spreads. (2020) Centers for Disease Control and

Prevention. https://www.cdc. gov/flu/about/disease/spread. htm. Accessed 15 Feb 2020.

6. Lu CW, Liu XF and Jia ZF. 2019-nCoV transmission through the ocular surface must not be ignored. Lancet. 2020;395(10224):e39.

7. Alert: Important coronavirus context for ophthalmologists. (2020) American Academy of Ophthalmology.

8. Lai THT, Tang EWH, Chau SKY, et al. stepping up infection control measures in ophthalmology during the novel coronavirus outbreak: an experience from Hong Kong. Graefes Arch Clin Exp 
Ophthalmol.

2020;

258(5):1049-55.

9. Guan W, Ni Z, Hu Y, et al.

Clinical characteristics of Coronavirus Disease 2019 in China. N Engl J Med. 2020. In press.

10. Lam DSC, Wong RLM, Lai KHW, et al. COVID-19: Special Precautions in Ophthalmic Practice and FAQs on Personal Protection and Mask Selection. Asia Pac J Ophthalmol (Phila). 2020;9(2):67-77.

11.Yong Y, Ruixue T, Xu S, et al. A comprehensive Chinese experience against SARSCoV-2 in ophthalmology. Eye Vis. 2020; 7:19.

12.Kampf G, Todt D, Pfaender $S$, et al. Persistence of coronaviruses on inanimate surfaces and their inactivation with biocidal agents. J Hosp Infect. 2020; 104(3):246-51.

13.Tran K, Cimon K, Severn $\mathbf{M}$, et al. Aerosol generating procedures and risk of transmission of acute respiratory infections to healthcare workers: a systematic review. PLoS One. 2012;7(4):e35797. 